\title{
The Mystery of P2X7 lonotropic Receptor: From a Small Conductance Channel to a Large Conductance Channel
}

\author{
R.X. Faria, L.G.B. Ferreira and L.A. Alves \\ Laboratory of Cellular Communication, \\ Oswaldo Cruz Institute, \\ Oswaldo Cruz Foundation, \\ Brazil
}

\section{Introduction}

\subsection{Ion channels}

Ion channels are aqueous pores which allow ions to pass based upon an electrochemical gradient. In order to conduct ions, these channels modify their shape by a process called gating, a shifting between opening and closing states. These channels are gated by various stimuli i.e. applied electric field, chemical transmitters, $\mathrm{pH}$, heat and cold, among others. When an electrical potential is held constant in a cell, the gating process equilibriates rather than reaching an energy-dissipating position (a cyclic steady state). Ions diffuse through open channels very fast, involving an interaction between ions, the pore, and solvent that lead to ionic selectivity, saturation, block and flux coupling (Hille, 1975a; Läuger, 1973a).

The ion channel has generally been viewed as having unchanging selectivity strengthening the argument that there is a degree of specificity between ion and channel. Nevertheless, some classes of ion channels present a more varied selectivity of ions, allowing impermeable ions or molecules to permeate under certain circumstances. However, the there is no a systematic approach to distinguish different ion channels and in most cases, it is necessary to differentiate the channels by their kinetics, molecular sequence, pharmacological properties, and response to ionic substitution.

The diversity of channels continues to pose numerous areas to explore in physiology, molecular biology, pharmacology and biophysics.(Hille, 1991). Ion channels are generally classified into two groups: the channels that allow the passage of ions $(\mathrm{Na}+, \mathrm{K}+, \mathrm{Ca} 2+)$ and those that allow the passage of large ions and solutes (ie ATP, glutamate, fluorescent dyes of low molecular weight). This second group is predominantly made up of large conductance ion channels which when activated change the permeability of cell membranes for molecules of up to 1000 Daltons (Ojcius, D. M. \& Ding-E Young, J., 1990; Iacovache et al, 2010). These channels are and allow for the secretion of ATP and other intracellular molecules, not to mention implicated in various mechanisms of cell death. 


\section{Proteins that form large channels in mammal cells}

These large channels are distinguished by their proteins which can be classified in accordance with their function, mechanism for membrane penetration, the size of their pores, its pore-forming subunits, and type of pore-forming proteins within the membrane plane $(\alpha-$ or $\beta$ ). By comparing the protein configuration in the plasma membrane it is possible to actually evolutionarily delineate the pore-forming protein of distinct organisms.

Proteins that form large conductance channels in the plasma membrane have been described in virus (Madan et al, 2007), bacteria (Huffman et al, 2004), fungi (Ojcius, D. M. \& Young, J. D., 1991) and plantae (Klüsener \& Weiler, 1999). Mostly due to these proteins being functionally linked to the mechanism of defense (plantae) or the invasion of the hosts (virus, bacteria, etc). These proteins are often secreted into the extracellular environment as monomers which then oligomerize and form the channel in the host membrane.

In humans and other mammals the secreted proteins, there have been found the antimicrobial peptide families of defensins (Kagan et al 1990) and cathelicidins (Scocchi et al, 1999; Skerlavaj et al, 2001). Other peptides, such as dermicidin (Boman et al 1993; Christensen et al, 1988) and anionic peptides (Brogden et al, 1996,1997,2003) are also found in tissue-specific areas. In the immune system, these pores cause physical damage to invading pathogens. In general, pore-forming proteins are monomeric molecules that interact with each other while they are inserted into membranes, where they continue to polymerize further to form large transmembrane pores, leading to a process of antimicrobial activity and cytotoxicity.

Generally, in vertebrates, more specifically in mammals, these pores are integral membrane proteins that are capable of opening under physiological or pathological condition. They can be found in several parts of the organism and may be associated with organism defense (release of pro-inflammatory agents, destruction of pathogens, cell death) or not (release of neurotransmissor, proliferation etc).

The main large conductance ion channels which are found in mammals, are the connexin hemichannels (Cx43, Cx32 and other), pannexins (pannexin-1), maxi anion channel, voltagedependent anionic channel (VDAC), maxi-K channel, maitotoxin pore, transient receptor potential vanilloid type-1 (TRPV1), transient receptor potential ankhirin type-1 (TRPA1) and ATP-activated P2X pores (P2X2, P2X4 and P2X7 receptors). All of these permit the passage of mono and divalent ions and the flow of molecules of up to $1000 \mathrm{Da}$. The majority of these large conductance ion channels are preferentially permeable to cations, while VDAC and maxi anion are permeable to anions. In addition, they are all permeable to the anionic ATP4molecule (Nagasawa et al, 2009; Pellegatti et al, 2005; Yip et al, 2009) and glutamate (Léon et al, 2008).

\section{P2X7 receptor associated pore}

Activation of the purinergic $\mathrm{P} 2 \mathrm{X}_{7}$ receptor (P2X7R) is rather unusual among ion channels. Brief agonist stimulation induces a non-selective cation-dependent pore, permitting the permeation of monovalent and divalent cations that leads to plasma membrane depolarization (Virginio et al, 1999b). By contrast, a prolonged and repetitive agonist application (at concentrations greater than $100 \mu \mathrm{M}$ ) promotes increased membrane 
permeability, allowing cellular uptake of fluorescent dyes such as propidium iodide (MW 639) or lucifer yellow (MW 457).

In the last years, some research groups have provided evidence that pannexin-1 (Panx1) hemichannel might be the protein associated with $\mathrm{P}_{2} \mathrm{X}_{7}$ receptor pore formation. However, several cells allow the passage of dyes, despite having the pannexin-1 channel blocked (Faria et al, 2005, 2010; Schachter et al 2008; Yan et al 2008). This opens the possibility that other proteins may participate in the formation of the large channel associated with the $\mathrm{P}_{2} \mathrm{X}_{7}$ receptor. As mentioned above, there are other proteins capable of forming large pores in plasma membrane.

In keeping with this idea, Faria and collaborators (2009) showed that calcium ionophores may massively increase the intracellular $\mathrm{Ca}^{2+}$ and induce dye uptake. They observed a pore with biophysical and pharmacological characteristics similar to $\mathrm{P}_{2} \mathrm{X}_{7}$ receptor pore (Figure 1). In addition, Schilling and colleagues (1999) observed the Maitotoxin opening, a pore able to uptake fluorescent dyes. This pore was also biophysically similar to the $\mathrm{P}_{2} \mathrm{X}_{7}$ receptor pore. Herein, we will address some questions about the possible protein candidate (or candidates) responsible for the $\mathrm{P}_{2} \mathrm{X}_{7}$ receptor pore formation described above. Moreover, we will discuss the possible events which might be occurring to regulate the opening of these pores in mammalian cells.

\section{Current methodologies to study large conductance channels}

\subsection{Patch clamp recordings}

In patch-clamp recording, the microelectrode is a micropipette with a relatively large tip diameter. The microelectrode is placed next to a cell and a gentle suction is applied through the microelectrode to draw a piece of the cell membrane (the 'patch') into the microelectrode tip; the glass tip forms a high resistance 'seal' with the cell membrane. The suction causes the cell to form a tight and high-resistance seal around electrode, resulting in a resistance of approximately 10 giga Ohms, which is called a gigaseal. There are several variations of the patch-clamp technique, as depicted in Figure 2.

\subsection{Cell permeabilization assays}

This technique allows the detection of plasma membrane permeabilization in different cell types, by inducing the activation and opening of large conductance channels. In general, we use low molecular weight fluorescent dyes, such as fluorescein, lucifer yellow, calcein, ethidium bromide, propidium iodide, in order to observe the entrance of these impermeable dyes after the permeabilization phenomenon.

$\mathrm{P} \mathrm{X}_{7}$ receptor pore-formation has been studied by several groups in different cell types. Most experiments associated with pore formation have centered around dye uptake experiments mediated by the $\mathrm{P} 2 \mathrm{X}_{7}$ receptor.

\subsection{Flow cytometry assays}

This is a technique for counting and examining microscopic particles, such as cells and chromosomes by suspending them in a stream of fluid and passing them through an 


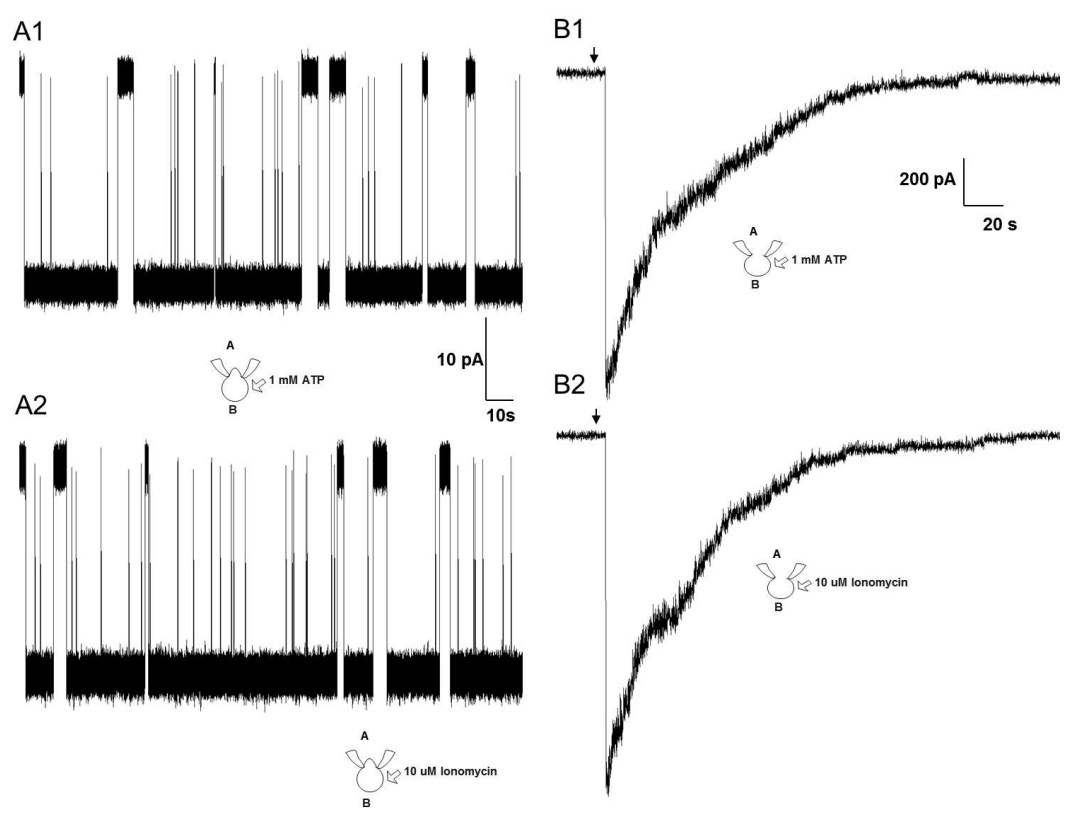

Fig. 1. Single channel and macroscopic currents in mouse peritoneal macrophages. The ionic currents were recorded at $37^{\circ} \mathrm{C}$ and holding potential of $-60 \mathrm{mV}$ using the cell attached configuration. A1- Single channel activity recorded after stimulation with $1 \mathrm{mM}$ ATP in the bath. A2- Single channel activity recorded after stimulation with 10uM Ionomycin in the bath. A3- Macroscopic current recorded after stimulation with 1mM ATP in the bath. A4Macroscopic current recorded after stimulation with 10uM ioniomycin in the bath. Arrows in figure B represent the moment of application of the agonists. Under each recording there is a schematic representing the electrophysiological configuration, the localization and the agonist concentration used. A- Intracellular saline: $150 \mathrm{mM} \mathrm{KCl}, 5 \mathrm{mM} \mathrm{NaCl}, 0.1 \mathrm{mM}$ EGTA, 10mM HEPES, pH 7.4. B- Extracellular saline: $150 \mathrm{mM} \mathrm{NaCl}, 5 \mathrm{mM} \mathrm{NaCl}, 1 \mathrm{mM} \mathrm{MgCl} 2+$, $1 \mathrm{mM} \mathrm{CaCl} 2+, 10 \mathrm{mM}$ Hepes, $\mathrm{pH} 7.4$.

electron detection apparatus. It allows the simultaneous multiparametric analysis of the physical and chemical characteristics of thousands of particles per second. Clinical and research laboratories uses flow cytometry, to analyze multiple cell parameters such as cell cycle, cell membrane alterations and cell phenotype. Several studies have used flow cytometry in dye uptake assays stimulating the pore forming protein to open and permit the entry of fluorescent dyes.

\subsection{Colorimetric assays}

The measurement most commonly used to detect effects of P2X7 activation is colorimetric assays which are based on the absorbance of light. In according to Beer's Law, a solute absorbs light of a particular wavelength, and the absorbance is directly proportional to the substance concentration in solution. The measurement is done by a spectrophotometer, displaying and recording absorbance in quantifiable units. In general, the substance of 

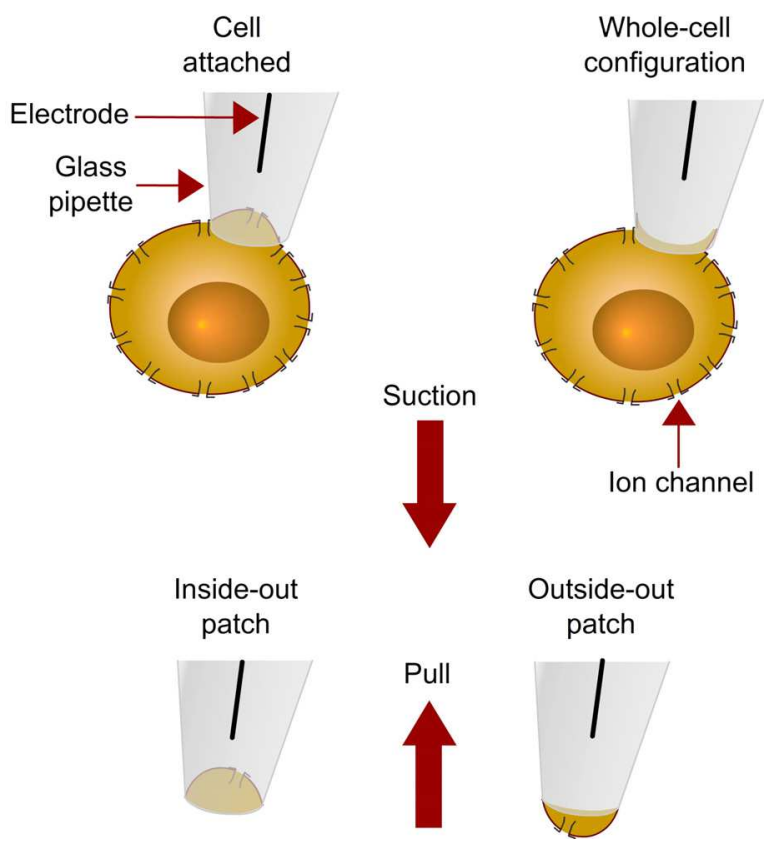

Fig. 2. Illustration of the different modes and configurations of the patch-clamp technique. In the cell-attached mode, the patch electrode remains sealed to the cell membrane, permitting the recording of currents through single-ion channels from the patch of membrane surrounded by the tip of the electrode. This configuration can be used for studying the activity of ion channels present in the membrane patch. In the whole cell mode, in the initial cell-attached configuration, additional suction is applied to rupture the cell membrane, thus providing access to the intracellular space. The larger opening at the tip of the patch electrode, compared with the sharp microelectrode, provides lower resistance and better electrical access to the cell- because the volume of the patch electrode is much bigger than the cell, cellular soluble contents will slowly be replaced by contents of the electrode, referred to as "dialyzing" the cell contents. Whole-cell mode records currents through all channels from the entire cell membrane at once. In the Inside-out patch mode, after the gigaseal are formed, the micropipette is quickly withdrawn from the cell, pulling off a patch of membrane from the cell, leaving the membrane patch attached to the micropipette, and exposing the intracellular surface of the membrane to the external media. This is useful when an experimenter wishes to pharmacologically manipulate the intracellular side of the ion channels. In the outside-out mode, after the whole-cell patch is formed, the electrode can be slowly withdrawn from the cell, allowing a bulb of membrane to bleb out from the cell. After the electrode to be pulled far enough away, this bleb will detach from the cell and reform as a convex membrane at the electrode end (like a ball open at the electrode tip), with the original outside of the membrane facing outward from the electrode. Single channel recordings are possible in this form if the membrane bleb is small enough. Outside-out patching gives the experimenter the opportunity to examine the properties of an ion channel when it is isolated from the cell, and exposed to different solutions on the extracellular membrane surface. 
interest, by itself, does not absorb light in the wavelength used. We have to apply one or more reagents to produce colored compounds which are proportional to the substance concentration of the unknown. These methodologies may be used to measure cell death (LDH release, MTT assay), release of substances (neurotransmissors, cytokines and others), uptake of substances (fluorescent dyes) and enzymatic activity.

\section{Electrophysiological studies of $P 2 X_{7}$}

The first group which published a unitary current associated with the $\mathrm{P} 2 \mathrm{X}_{7}$ pore was Coutinho-Silva and coworkers in 1997. They used a cell attached configuration in mouse macrophages to show that the $\mathrm{P} \mathrm{X}_{7}$ receptor when activated by ATP (in milimolar concentrations), is able to activate a large conductance channel with unitary conductance of about 400 pS (Coutinho-Silva et al, 1997). These pores were voltage dependent and had properties similar to P2Z permeabilization, such as uptake of large cations (N-methyl-Dglucamine) and anions (glutamate). Their opening is favored at temperatures higher than 30 degree Celsius and is blocked by oxidized ATP and $\mathrm{Mg}^{2+}$. These authors did not record this conductance in excised patches which was the first clue for the participation of secondary messengers and cytoskeletal proteins.

After this discovery, other groups used cell attached configuration however only in low

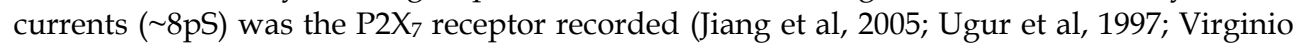
et al, 1997). The large conductance activity was detected in dye uptake assays (Jiang et al, 2005; Hibell et al, 2000; Virginio et al, 1997;) or in whole cell experiments. In the whole cell, the macroscopic current induced by ATP or BzATP (a synthetic analog more potent than ATP) could be divided, according to some reports, into two distinct conductance (or components). The first component are the small channels opening and the second component is related to the large conductance of the $\mathrm{P} 2 \mathrm{X}_{7}$ receptor (Jiang et al, 2005; Virginio et al, 1999).

In 2005, our group, using cell attached configuration, recorded a unitary conductance of approximately $400 \mathrm{pS}$ in murine macrophages and 2BH4 cells (Faria et al, 2005). We observed a linear response in positive and negative holding potential however this large conductance channel was never observed in excised patch, supporting that there is a dependence of intracellular signals as previously suggested by Coutinho-Silva's studies (Faria et al, 2005). In addition it was found that blockers of the $\mathrm{P}_{2} \mathrm{X}_{7}$ receptor reduced the conductance and were modulated by the intracellular $\mathrm{Ca}^{2+}$ and MAPK. On the otherhand, Riedel's group in 2007, using the patch-clamp technique, studied the influence of external alkali and organic monovalent cations on the single-channel properties of the human $\mathrm{P}_{2} \mathrm{X}_{7}$ receptor. In cell attached and excised patches, they observed activity only of the small conductance channel. Interestingly, they also reported an increased probability of $\mathrm{P}_{2} \mathrm{X}_{7}$ small channel opening when extracellular $\mathrm{Na}^{+}$was substituted for other monovalent cations (Riedel et al, 2007a). This same group used human P2X $X_{7}$ receptors expressed in Xenopus laevis oocytes and recorded single channels using the patch-clamp technique in the outsideout configuration. The result observed was similar to the previous paper as the large conductance channel was not observed (Riedel et al 2007b).

In 2008, Schachter and coworkers compared the $\mathrm{P} 2 \mathrm{X}_{7}$ receptor pore formation of macrophages and HEK-293 cells transfected with $\mathrm{P}_{2} \mathrm{X}_{7}$ (HEK-P2X(7) ) receptors using patch- 
clamp recordings. They did not record a unitary conductance activity in transfected HEK293 cells. A pore with conductance of approximately 400 pS was recorded only in mouse peritoneal macrophages. Using dye uptake experiments, they also observed the differential uptake of cations and anions between the endogenous $\mathrm{P} 2 \mathrm{X}_{7}$ receptor pore formation in macrophages. The anionic pathways associated with the large conductance channel and the cationic pathway were unidentified (Schachter et al, 2008).

In 2009, based on previous data reporting that increasing intracellular $\mathrm{Ca}^{2+}$ is able to induce the opening of a pore biophysically similar to the $\mathrm{P}_{2} \mathrm{X}_{7}$ receptor pore. Investigating this channel we found that calcium ionophores at micromolar concentrations induced dye uptake and ionic currents presented a unitary conductance of $400 \mathrm{pS}$, in the attached cell. This pore was unaffected by $\mathrm{P} 2 \mathrm{X}_{7}$ receptor blockers, but it had intracellular signaling components similar to the $\mathrm{P}_{2} \mathrm{X}_{7}$ receptor large conductance channel and not observed in excised patches. However, we did not identify the entity responsible for inducing intracellular $\mathrm{Ca}^{2+}$ pore opening in mouse macrophages and 2BH4 cells (Faria et al, 2009).

In 2010, Yan and collaborators performed experiments to understand how the three binding site occupation for the ATP may affect the $\mathrm{P}_{2} \mathrm{X}_{7}$ receptor gating. They showed that ATP concentrations in the milimolar range were able to biphasically activate and deactivate native receptors while micromolar concentrations responded monophasically. Both phases of response were abolished by the application of Az10606120, a P2X 7 R-specific antagonist. This slow secondary growth of current in the biphasic response coincided temporally with pore dilation. This pore current was insensitive to $\mathrm{Na}^{+}$and $\mathrm{Ca}^{2+}$ influx and fully reestablished the initial gating properties after $30 \mathrm{~min}$ of washout. The complex pattern of gating exhibited by wild-type channels can be accounted for by the Markov state model that includes the negative cooperativity of agonist binding to unsensitized receptors caused by the occupancy of one or two binding sites, thus opening the channel pore to a low conductance state when the two sites are bound, and when three sites are occupied, triggering a high conductance state (pore dilation) (Yan et al, 2010). In contrast, Flittiger and collaborators while investigating the participation of protons in the activation of $h P 2 X_{7} \mathrm{Rs}$ observed that human $\mathrm{P}_{2} \mathrm{X}_{7}$ receptors expressed in Xenopus laevis oocytes were activated by ATP or BzATP at different $\mathrm{pH}$ values. The unitary currents were blocked by protonation and the large conductance channel not recorded (Flittiger et al, 2010).

In 2010, Roger and coworkers, used a whole cell configuration to characterize the functional properties of the biphasic ionic conductance recorded in human and rat $\mathrm{P} 2 \mathrm{X}_{7}$ receptors. They observed that in humans there was a $\mathrm{Ca}^{2+} /$ calmodulin independence of the secondary conductance (pore), while in rats there was dependency (Roger et al, 2010)

\section{The search of large channels associated with $P 2 X_{7}$}

In search of the $\mathrm{P}_{2} \mathrm{X}_{7}$ receptor protein responsible for large unitary conductance and the pore that is induced rising intracellular $\mathrm{Ca}^{2+}$ (Faria et al, 2009) we compared the main biophysical properties of the other large conductance channels with these types of pores.

In cultured cells under resting conditions, hemichannels have a low open probability at negative membrane potentials, and the open probability is increased at positive potentials (Bukauskas \& Verselis, 2004). Increases in hemichannel levels have been clearly associated 
with rises in intracellular-free $\mathrm{Ca}^{2+}$ concentration $\left(\left[\mathrm{Ca}^{2+}\right]_{\mathrm{i}}\right.$ ) (Schalper et al, 2008, Sánchez et al, 2009). Normally, positive membrane potentials activate the fast gating, which corresponds to fast transitions between the fully open state and a substate. At negative membrane potentials, the loop gating activates slow transitions, perhaps involving multiple substates between the fully open state, substates and the fully closed state (Bukauskas \& Verselis, 2004). Unitary conductance of the connexin hemichannel recorded in a cell attached configuration exhibited conductance values of approximately $300 \mathrm{pS}$ for connexin 56 (Ebihara et al, 1999), for connexin 43 approximately of 200 pS (Contreras et al, 2003a, 2003b; Kang et al, 2008; Retamal et al, 2007b), 250 pS for connexin 46 (Ma \& Dahl, 2006) and 200 pS for connexin 50 hemichannel (Liu et al, 2011).

Panx1 channels have been reported with different voltage dependence. In some cases, Panx1-mediated currents are outwardly rectifying and require a depolarization for activation (R. Bruzzone et al, 2003, Pelegrin et al, 2006). This observation is at odds with currents recorded in pyramidal neurons following Panx1 activation by ischemia or NMDAR stimulatio, where the current-voltage (I-V) relationship is clearly linear (Thompson et al, 2006, 2008a, 2008b) similar to Panx1 when it is conducting ATP (Bao et al, 2004). Upon activation, pannexons open into large non-selective pores, which are insensitive to physiological levels of extracellular $\mathrm{Ca}^{2+}$ but they are permeable to ions and small molecules as well as metabolites of up to $1000 \mathrm{Da}$ and a wide range of membrane depolarization levels (S. Bruzzone et al, 2004). In addition, some groups have measured the unitary conductance of this large conductance channel, which is approximately 500 pS (Bao et al, 2004; Locovei et al, 2006; Thompson et al, 2006) which suggests that depolarization activates rectifying Panx1 currents and that other mechanisms lead to currents that are not significantly rectifying.

The presence of VDAC in the plasma membrane (pl-VDAC) would be expected to be lethal to the cell ( $\mathrm{Yu}$ and Forte, 1996). However, considering the resting membrane potential across the plasma membrane of about -30 to $-60 \mathrm{mV}$ (Dermietzel et al, 1994), VDAC1 in the plasma membrane would be in a closed state most of the time (Mannella, 1997). Current events were recorded from excised patches of plasma membranes of a rat astrocytic cell line (RGCN)where it was found that the underlying channels exhibited a conductance from 401 to 250 pS. Open probability was the highest between $210 \mathrm{mV}$, and gradually approached zero beyond $225 \mathrm{mV}$. Activity induced by voltage ramps between $240 \mathrm{mV}$ appeared after a several minute delay.

Several authors have reported the single-channel opening of the Maxi-anion with larger unitary conductance (300-400 pS) recorded in the cell-attached mode after cell swelling (Dutta et al, 2004; Liu et al, 2006, 2008a). Most authors noted that the maxi-anion channel has multiple subconductance states of various levels, such as 15, 50, 100, 150 and 200 pS (Dutta et al, 2004; Olesen \& Bundgaard, 1992; Schwarze \& Kolb, 1984; Akanda et al, 2008). When the extracellular $\mathrm{Cl}^{-}$concentration varied, the single-channel conductance saturated at 640 pS with $\mathrm{Km}=112 \mathrm{mM}$ in L6 myoblasts (Hurnák \& Zachar, 1994), at 581 pS with Km = 120 $\mathrm{mM}$ in T lymphocytes (Schlichter et al, 1990) and at $617 \mathrm{pS}$ with $\mathrm{Km}=77 \mathrm{mM}$ in frog skeletal muscle "sarcoballs" (Hals et al, 1989). The maxi-anion channel presents roughly uniform behavior in different cell types. The current-voltage relationship of the fully open state is usually symmetrical and linear with no rectification when it is recorded by cell attached configuration. The channel has a maximal open channel probability at around $0 \mathrm{mV}$, but it readily closes when the voltage exceeds a range of \pm 15 to $\pm 30 \mathrm{mV}$. The macroscopic currents 
exhibit a time dependent inactivation at large positive and negative potentials over \pm 15 to $+30 \mathrm{mV}$. The voltage dependence of open probability (Popen) remains bell-shaped with maximum at a voltage near $0 \mathrm{mV}$. These results indicate that the channel is highly selective to anions (Mitchell et al, 1997; Schlichter et al, 1990) but that the degree of anion selectivity may vary (Bajnath et al, 1993, Kemp et al, 1993) not only with cell types but also with the experimental conditions.

TRPV1 is a nonselective cation channel which is structurally related to the voltage-activated potassium $(\mathrm{Kv})$ channels. The TRPV1 expressed alone in human embryonic kidney-derived HEK293 cells or Xenopus oocytes can account for the majority of the electrophysiological properties exhibited by native capsaicin receptors in sensory neurons, including ligand affinity, permeability sequence, current/voltage (I/V) relationship, conductance and open probability at both single-channel and whole-cell levels.

In whole cell configuration, I/V relationships have reversal potentials close to $0 \mathrm{mV}$, indicating the opening of non-selective cationic channels, and a substantial outwards rectification with a region of negative slope conductance at potentials negative to $+70 \mathrm{mV}$ (Gunthorpe et al, 2000).

In cell attached configuration, the single-channel amplitude histogram showed two well separated peaks representing open and closed states, without sub-conductance levels observed at $+60 \mathrm{mV}$. The single-channel amplitude at $+60 \mathrm{mV}$ was $5.3 \mathrm{pA}$, corresponding to a conductance of $88.3 \mathrm{pS}$. Open probability depends on membrane potential as it has been shown in single-channel and whole-cell recordings (Premkumar et al. 2002; Voets et al. 2004b). At the molecular level, an extracellular $\mathrm{Ca}^{2+}$-dependent reduction of TRPV1 responsiveness upon continuous vanilloid exposure (electrophysiological desensitization) may underlie this phenomenon, at least in part (Caterina et al, 1997; Szallasi \& Blumberg, 1999). In relation to TRPV1 large conductance formation, some papers have published that this channel may mediate fluorescent dye uptake, however they did not characterize the biophysical properties related to this phenomenon (Blumberg, 2007; Hellwig et al, 2004; Myrdal \& Steeiger, 2005). Since 2008, other research groups have now characterized this second stage of conductance of the TRPV1 channel.

MTX may initially induce the activation of a NSCC, which is permeable to $\mathrm{Na}+$ and $\mathrm{K}+$, but it has a low permeability to Ca2+ (Schilling et al., 1999; de la Rosa et al., 2007). MTX may also increase [Ca2+]i via various $\mathrm{Ca}^{2+}$ entry pathways following depolarization, including Ltype voltage-sensitive $\mathrm{Ca}^{2+}$ channels (VSCCs), which are the predominant $\mathrm{Ca}^{2+}$ channel type in vascular smooth muscle (Sanders, 2001). The unitary conductance was 12 pS in the presence of $50 \mathrm{mM} \mathrm{Ba}^{2+}$. Within a burst, the distribution of opening times was a single exponential with a mean open time of $10.4 \mathrm{~ms}$ (Kobayashi et al, 1987-Br J Pharmacol). GH4C1 rat pituitary cells were stimulated with independent currents of an MTX-induced steady-state voltage of nearly $400 \mathrm{pS} / \mathrm{pF}$ within seconds of addition to the bath. Ion substitution experiments demonstrated that these ionic currents are consistent with the conductance of sodium and chloride, but not calcium ions (Young et al, 1995).

\section{Conclusion}

In summary, Maxi anion and pl-VDAC had unitary conductance of $400 \mathrm{pS}$, but were voltage-dependent and anionic. In relation to Maitotoxin and TRPV1 pores which were not 
recorded in cell attached configuration yet their whole cell characteristics are similar. In addition, pannexin- 1 hemichannels had unitary conductance of approximately $500 \mathrm{pS}$ and could be activated by intracellular $\mathrm{Ca}^{2+}$, though when this channel is activated by voltage its biophysical properties change. Altogether, these data show how complex and difficult is to characterize or rule out the participation of these proteins in the $\mathrm{P}_{2} \mathrm{X}_{7}$ receptor large conductance.

A better understanding of the molecular mechanism for P2X7 pore formation might open new therapeutic strategies since this receptor is involved in several processes such as the killing of intracellular pathogens, chronic inflammation, neuropathic pain and rheumatoid arthritis.

So, despite the important efforts carried out in the studies of P2X7 receptor, the pore opening mechanism (large channel) is still unknown.

\section{References}

Akanda, N., Tofighi, R., Brask, J.,Tamm, C.,Elinder, F.\& Ceccatelli, S. Voltage-dependent anion channels (VDAC) in the plasma membrane play a critical role in apoptosis in differentiated hippocampal neurons but not in neural stem cells. Cell Cycle, v. 7, n. 20, p. 3225-34, Oct 2008. ISSN 1551-4005.

Bajnath, R. B., Groot, J. A., de Jonge, H. R., Kansen, M. \& Bijman, J.. Calcium ionophore plus excision induce a large conductance chloride channel in membrane patches of human colon carcinoma cells HT-29cl.19A. Experientia, v. 49, n. 4, p. 313-6, Apr 1993. ISSN 0014-4754.

Bao, L.; Locovei, S. \& Dahl, G. Pannexin membrane channels are mechanosensitive conduits for ATP. FEBS Lett, v. 572, n. 1-3, p. 65-8, Aug 2004. ISSN 0014-5793.

Blumberg, P. M. Lighting a backfire to quench the blaze: a combined drug approach targeting the vanilloid receptor TRPV1. Mol Interv, v. 7, n. 6, p. 310-2, Dec 2007. ISSN 1534-0384.

Boman, H. G.; Agerberth, B.; Boman, A. Mechanisms of action on Escherichia coli of cecropin P1 and PR-39, two antibacterial peptides from pig intestine. Infect Immun, v. 61, n. 7, p. 2978-84, Jul 1993. ISSN 0019-9567. >.

Brogden, K. A., Ackermann, M., McCray, P. B. \& Tack, B. F. Antimicrobial peptides in animals and their role in host defences. Int J Antimicrob Agents, v. 22, n. 5, p. 465-78, Nov 2003. ISSN 0924-8579.

Brogden, K. A., De Lucca, A. J., Bland, J. \& Elliott, S. Isolation of an ovine pulmonary surfactant-associated anionic peptide bactericidal for Pasteurella haemolytica. Proc Natl Acad Sci U S A, v. 93, n. 1, p. 412-6, Jan 1996b. ISSN 0027-8424.

Brogden, K. A.; Ackermann, M.; Huttner, K. M. Small, anionic, and charge-neutralizing propeptide fragments of zymogens are antimicrobial. Antimicrob Agents Chemother, v. 41, n. 7, p. 1615-7, Jul 1997. ISSN 0066-4804.

Bruzzone, R., Hormuzdi, S. G.,Barbe, M. T.,Herb, A. \& Monyer, H. Pannexins, a family of gap junction proteins expressed in brain. Proc Natl Acad Sci U S A, v. 100, n. 23, p. 13644-9, Nov 2003. ISSN 0027-8424. 
Bruzzone, S., Verderio, C., Schenk, U., Fedele, E., Zocchi, E., Matteoli, M. \& De Flora, A. Glutamate-mediated overexpression of CD38 in astrocytes cultured with neurones. J Neurochem, v. 89, n. 1, p. 264-72, Apr 2004. ISSN 0022-3042

Bukauskas, F. F. \& Verselis, V. K. Gap junction channel gating. Biochim Biophys Acta, v. 1662, n. 1-2, p. 42-60, Mar 2004. ISSN 0006-3002.

Caterina, M. J., Schumacher, M. A., Tominaga, M., Rosen, T. A., Levine, J. D. \& Julius, D. The capsaicin receptor: a heat-activated ion channel in the pain pathway. Nature, v. 389, n. 6653, p. 816-24, Oct 1997. ISSN 0028-0836.

Cavaliere, F.; Dinkel, K. \& Reymann, K. Microglia response and P2 receptor participation in oxygen/glucose deprivation-induced cortical damage. Neuroscience, v. 136, n. 3, p. 615-23, 2005. ISSN 0306-4522.

Christensen, B., Fink, J., Merrifield, R. B. \& Mauzerall, D.. Channel-forming properties of cecropins and related model compounds incorporated into planar lipid membranes. Proc Natl Acad Sci U S A, v. 85, n. 14, p. 5072-6, Jul 1988. ISSN 00278424.

Contreras, J. E., Sáez, J. C., Bukauskas, F. F. \& Bennett, M. V. Functioning of cx43 hemichannels demonstrated by single channel properties. Cell Commun Adhes, v. 10, n. 4-6, p. 245-9, 2003 Jul-Dec 2003a. ISSN 1541-9061.

Contreras, J. E., Sáez, J. C., Bukauskas, F. F. \& Bennett, M. V.. Gating and regulation of connexin 43 (Cx43) hemichannels. Proc Natl Acad Sci U S A, v. 100, n. 20, p. 1138893, Sep 2003b. ISSN 0027-8424.

Coutinho-Silva, R. \& Persechini, P. M. P2Z purinoceptor-associated pores induced by extracellular ATP in macrophages and J774 cells. Am J Physiol, v. 273, n. 6 Pt 1, p. C1793-800, Dec 1997. ISSN 0002-9513.

de la Rosa, L. A., Alavarez-Parrilla, E. \& Martínez-Martínez, A. Biochemistry of Maitotoxin, in Phycotoxins: Chemistry and Biochemistry. Blackwell Publishing, Ames, Iowa, USA: 2007. ISBN 9780470277874.

Dermietzel, R., Hwang, T. K., Buettner, R., Hofer, A., Dotzler, E., Kremer, M., Deutzmann, R., Thinnes, F. P., Fishman, G. I. \& Spray, D. C.. Cloning and in situ localization of a brain-derived porin that constitutes a large-conductance anion channel in astrocytic plasma membranes. Proc Natl Acad Sci U S A, v. 91, n. 2, p. 499-503, Jan 1994. ISSN 0027-8424.

Duan, S., Anderson, C. M., Keung, E. C., Chen, Y. \& Swanson, R. A.. P2X7 receptormediated release of excitatory amino acids from astrocytes. J Neurosci, v. 23, n. 4, p. 1320-8, Feb 2003. ISSN 1529-2401.

Dutta, A. K., Sabirov, R. Z., Uramoto, H. \& Okada, Y.. Role of ATP-conductive anion channel in ATP release from neonatal rat cardiomyocytes in ischaemic or hypoxic conditions. J Physiol, v. 559, n. Pt 3, p. 799-812, Sep 2004. ISSN 0022-3751.

Ebihara, L., Xu, X., Oberti, C., Beyer, E. C. \& Berthoud, V. M.. Co-expression of lens fiber connexins modifies hemi-gap-junctional channel behavior. Biophys J, v. 76, n. 1 Pt 1, p. 198-206, Jan 1999. ISSN 0006-3495.

Faria, R. X., Cascabulho, C. M., Reis, R. A. \& Alves, L. A.. Large-conductance channel formation mediated by $\mathrm{P} 2 \mathrm{X7}$ receptor activation is regulated through distinct intracellular signaling pathways in peritoneal macrophages and 2BH4 cells. Naunyn Schmiedebergs Arch Pharmacol, v. 382, n. 1, p. 73-87, Jul 2010. ISSN 1432-1912. 
Faria, R. X., Reis, R. A., Casabulho, C. M., Alberto, A. V., de Farias, F. P., Henriques-Pons, A. \& Alves, L. A.. Pharmacological properties of a pore induced by raising intracellular Ca2+. Am J Physiol Cell Physiol, v. 297, n. 1, p. C28-42, Jul 2009. ISSN 1522-1563.

Faria, R. X.; DeFARIAS, F. P. \& Alves, L. A. Are second messengers crucial for opening the pore associated with P2X7 receptor? Am J Physiol Cell Physiol, v. 288, n. 2, p. C26071, Feb 2005. ISSN 0363-6143.

Flittiger, B., Klapperstück, M., Schmalzing, G. \& Markwardt, F.. Effects of protons on macroscopic and single-channel currents mediated by the human P2X7 receptor. Biochim Biophys Acta, v. 1798, n. 5, p. 947-57, May 2010. ISSN 0006-3002.

Gunthorpe, M.J., Harries, M.H., Prinjha, R.K., Davis, J.B., \& Randall, A.. Voltage-and timedependent properties of the recombinat rat vanilloid receptor. Journal of Physiology: 747-759 p. 2000.

Hals, G. D.; Stein, P. G. \& Palade, P. T. Single channel characteristics of a high conductance anion channel in "sarcoballs". J Gen Physiol, v. 93, n. 3, p. 385-410, Mar 1989. ISSN 0022-1295.

Hellwig, N., Plant, T. D., Janson, W., Schäfer, M., Schultz, G. \& Schaefer, M.. TRPV1 acts as proton channel to induce acidification in nociceptive neurons. J Biol Chem, v. 279, n. 33, p. 34553-61, Aug 2004. ISSN 0021-9258.

Hibell, A. D., Kidd, E. J., Chessell, I. P., Humphrey, P. P. \& Michel, A. D.. Apparent species differences in the kinetic properties of P2X(7) receptors. Br J Pharmacol, v. 130, n. 1, p. 167-73, May 2000. ISSN 0007-1188.

Hille, B. . Ionic selectivity of $\mathrm{Na}$ and $\mathrm{K}$ channels of nerve membranes. Membranes, v. 3, p. 255-323, 1975. ISSN 0076-6356.

Huffman, D. L., Bischof, L. J., Griffitts, J. S. \& Aroian, R. V.. Pore worms: using Caenorhabditis elegans to study how bacterial toxins interact with their target host. Int J Med Microbiol, v. 293, n. 7-8, p. 599-607, Apr 2004. ISSN 1438-4221.

Hurnák, O. \& Zachar, J. Conductance-voltage relations in large-conductance chloride channels in proliferating L6 myoblasts. Gen Physiol Biophys, v. 13, n. 3, p. 171-92, Jun 1994. ISSN 0231-5882.

Iacovache, I.; Bischofberger, M. \& Van der Goot, F. G. Structure and assembly of poreforming proteins. Curr Opin Struct Biol, v. 20, n. 2, p. 241-6, Apr 2010. ISSN 1879033X.

Jiang, L. H., Rassendren, F., Mackenzie, A., Zhang, Y. H., Surprenant, A. \& North, R. A.. Nmethyl-D-glucamine and propidium dyes utilize different permeation pathways at rat P2X(7) receptors. Am J Physiol Cell Physiol, v. 289, n. 5, p. C1295-302, Nov 2005. ISSN 0363-6143.

Kang, J., Kang, N., Lovatt, D., Torres, A., Zhao, Z., Lin, J. \& Nedergaard, M.. Connexin 43 hemichannels are permeable to ATP. J Neurosci, v. 28, n. 18, p. 4702-11, Apr 2008. ISSN 1529-2401.

Kawamura, H., Aswad, F., Minagawa, M., Malone, K., Kaslow, H., Koch-Nolte, F., Schott, W. H., Leiter, E. H. \& Dennert, G.. P2X7 receptor-dependent and -independent T cell death is induced by nicotinamide adenine dinucleotide. J Immunol, v. 174, n. 4, p. 1971-9, Feb 2005. ISSN 0022-1767. 
Kemp, P. J. \& Boyd, C. A. Anion exchange in type II pneumocytes freshly isolated from adult guinea-pig lung. Pflugers Arch, v. 425, n. 1-2, p. 28-33, Oct 1993. ISSN 00316768.

Klüsener, B. \& Weiler, E. W. Pore-forming properties of elicitors of plant defense reactions and cellulolytic enzymes. FEBS Lett, v. 459, n. 2, p. 263-6, Oct 1999. ISSN 0014-5793.

Kobayashi, M. \& Ochi, R.; Ohizumi, Y. Maitotoxin-activated single calcium channels in guinea-pig cardiac cells. Br J Pharmacol, v. 92, n. 3, p. 665-71, Nov 1987. ISSN 00071188.

Läuger, P. Ion transport through pores: a rate-theory analysis. Biochim Biophys Acta, v. 311, n. 3, p. 423-41, Jul 1973. ISSN 0006-3002.

León, D., Sánchez-Nogueiro, J., Marín-García, P. \& Miras-Portugal, M. A.. Glutamate release and synapsin-I phosphorylation induced by P2X7 receptors activation in cerebellar granule neurons. Neurochem Int, v. 52, n. 6, p. 1148-59, May 2008. ISSN 0197-0186.

Lister, M. F., Sharkey, J., Sawatzky, D. A., Hodgkiss, J. P., Davidson, D. J., Rossi, A. G. \& Finlayson, K.. The role of the purinergic P2X7 receptor in inflammation. J Inflamm (Lond), v. 4, p. 5, 2007. ISSN 1476-9255.

Liu, H. T., Tashmukhamedov, B. A., Inoue, H., Okada, Y. \& Sabirov, R. Z.. Roles of two types of anion channels in glutamate release from mouse astrocytes under ischemic or osmotic stress. Glia, v. 54, n. 5, p. 343-57, Oct 2006. ISSN 0894-1491.

Liu, H. T., Toychiev, A. H., Takahashi, N., Sabirov, R. Z. \& Okada, Y. Maxi-anion channel as a candidate pathway for osmosensitive ATP release from mouse astrocytes in primary culture. Cell Res, v. 18, n. 5, p. 558-65, May 2008. ISSN 1748-7838.

Liu, J., Ek Vitorin, J. F., Weintraub, S. T., Gu, S., Shi, Q., Burt, J. M. \& Jiang, J. X.. Phosphorylation of connexin 50 by protein kinase A enhances gap junction and hemichannel function. J Biol Chem, v. 286, n. 19, p. 16914-28, May 2011. ISSN 1083$351 X$.

Locovei, S.; Bao, L. \& Dahl, G. Pannexin 1 in erythrocytes: function without a gap. Proc Natl Acad Sci U S A, v. 103, n. 20, p. 7655-9, May 2006. ISSN 0027-8424.

Ma, M. \& Dahl, G. Cosegregation of permeability and single-channel conductance in chimeric connexins. Biophys J, v. 90, n. 1, p. 151-63, Jan 2006. ISSN 0006-3495.

Madan, R. P., Mesquita, P. M., Cheshenko, N., Jing, B., Shende, V., Guzman, E., Heald, T., Keller, M. J., Regen, S. L., Shattock, R. J. \& Herold, B. C. Molecular umbrellas: a novel class of candidate topical microbicides to prevent human immunodeficiency virus and herpes simplex virus infections. J Virol, v. 81, n. 14, p. 7636-46, Jul 2007. ISSN 0022-538X.

Mannella, C. A. Minireview: on the structure and gating mechanism of the mitochondrial channel, VDAC. J Bioenerg Biomembr, v. 29, n. 6, p. 525-31, Dec 1997. ISSN 0145479X.

Mariathasan, S., Weiss, D. S., Newton, K., McBride, J., O'Rourke, K., Roose-Girma, M., Lee, W. P., Weinrauch, Y., Monack, D. M. \& Dixit, V. M.. Cryopyrin activates the inflammasome in response to toxins and ATP. Nature, v. 440, n. 7081, p. 228-32, Mar 2006. ISSN 1476-4687.

Milius, D., Gröger-Arndt, H., Stanchev, D., Lange-Dohna, C., Rossner, S., Sperlagh, B., Wirkner, K. \& Illes, P.. Oxygen/glucose deprivation increases the integration of recombinant P2X7 receptors into the plasma membrane of HEK293 cells. Toxicology, v. 238, n. 1, p. 60-9, Aug 2007. ISSN 0300-483X. 
Mitchell, C. H., Zhang, J. J., Wang, L. \& Jacob, T. J.. Volume-sensitive chloride current in pigmented ciliary epithelial cells: role of phospholipases. Am J Physiol, v. 272, n. 1 Pt 1, p. C212-22, Jan 1997. ISSN 0002-9513.

Myrdal, S. E. \& Steyger, P. S. TRPV1 regulators mediate gentamicin penetration of cultured kidney cells. Hear Res, v. 204, n. 1-2, p. 170-82, Jun 2005. ISSN 0378-5955.

Nagasawa, K.; Escartin, C. \& Swanson, R. A. Astrocyte cultures exhibit P2X7 receptor channel opening in the absence of exogenous ligands. Glia, v. 57, n. 6, p. 622-33, Apr 2009. ISSN 1098-1136.

Ojcius, D. M. \& Ding-E Young, J. A role for pore-forming proteins in the pathogenesis by parasites? Parasitol Today, v. 6, n. 5, p. 163-5, May 1990. ISSN 0169-4758.

Ojcius, D. M. \& Young, J. D. Cytolytic pore-forming proteins and peptides: is there a common structural motif? Trends Biochem Sci, v. 16, n. 6, p. 225-9, Jun 1991. ISSN 0968-0004.

Olesen, S. P. \& Bundgaard, M. Chloride-selective channels of large conductance in bovine aortic endothelial cells. Acta Physiol Scand, v. 144, n. 2, p. 191-8, Feb 1992. ISSN 00016772.

Papp, L., Vizi, E. S. \& Sperlágh, B. Lack of ATP-evoked GABA and glutamate release in the hippocampus of P2X7 receptor-/- mice. Neuroreport, v. 15, n. 15, p. 2387-91, Oct 2004. ISSN 0959-4965.

Pelegrin, P. \& Surprenant, A. Pannexin-1 mediates large pore formation and interleukin1beta release by the ATP-gated P2X7 receptor. EMBO J, v. 25, n. 21, p. 5071-82, Nov 2006. ISSN 0261-4189.

Pellegatti, P., Falzoni, S., Pinton, P., Rizzuto, R. \& Di Virgilio, F.. A novel recombinant plasma membrane-targeted luciferase reveals a new pathway for ATP secretion. Mol Biol Cell, v. 16, n. 8, p. 3659-65, Aug 2005. ISSN 1059-1524.

Premkumar, L. S.; Agarwal, S.; Steffen, D. Single-channel properties of native and cloned rat vanilloid receptors. J Physiol, v. 545, n. Pt 1, p. 107-17, Nov 2002. ISSN 0022-3751.

Retamal, M. A., Froger, N., Palacios-Prado, N., Ezan, P., Sáez, P. J., Sáez, J. C. \& Giaume, C.. Cx43 hemichannels and gap junction channels in astrocytes are regulated oppositely by proinflammatory cytokines released from activated microglia. J Neurosci, v. 27, n. 50, p. 13781-92, Dec 2007. ISSN 1529-2401.

Riedel, T., Lozinsky, I., Schmalzing, G. \& Markwardt, F.. Kinetics of P2X7 receptor-operated single channels currents. Biophys J, v. 92, n. 7, p. 2377-91, Apr 2007. ISSN 0006-3495.

Riedel, T., Schmalzing, G. \& Markwardt, F. Influence of extracellular monovalent cations on pore and gating properties of P2X7 receptor-operated single-channel currents. Biophys J, v. 93, n. 3, p. 846-58, Aug 2007. ISSN 0006-3495.

Roger, S., Gillet, L., Baroja-Mazo, A., Surprenant, A. \& Pelegrin, P.. C-terminal calmodulinbinding motif differentially controls human and rat P2X7 receptor current facilitation. J Biol Chem, v. 285, n. 23, p. 17514-24, Jun 2010. ISSN 1083-351X.

Sánchez, H. A., Orellana, J. A., Verselis, V. K. \& Sáez, J. C.. Metabolic inhibition increases activity of connexin-32 hemichannels permeable to Ca2+ in transfected HeLa cells. Am J Physiol Cell Physiol, v. 297, n. 3, p. C665-78, Sep 2009. ISSN 1522-1563.

Sanders, K. M. Invited review: mechanisms of calcium handling in smooth muscles. J Appl Physiol, v. 91, n. 3, p. 1438-49, Sep 2001. ISSN 8750-7587.

Schachter, J., Motta, A. P., de Souza Zamorano, A., da Silva-Souza, H. A., Guimarães, M. Z. \& Persechini, P. M.. ATP-induced P2X7-associated uptake of large molecules 
involves distinct mechanisms for cations and anions in macrophages. J Cell Sci, v. 121, n. Pt 19, p. 3261-70, Oct 2008. ISSN 0021-9533.

Schalper, K. A., Palacios-Prado, N., Retamal, M. A., Shoji, K. F., Martínez, A. D. \& Sáez, J. C.. Connexin hemichannel composition determines the FGF-1-induced membrane permeability and free [Ca2+]i responses. Mol Biol Cell, v. 19, n. 8, p. 3501-13, Aug 2008. ISSN 1939-4586.

Schilling, W. P.; Sinkins, W. G. \& Estacion, M. Maitotoxin activates a nonselective cation channel and a P2Z/P2X(7)-like cytolytic pore in human skin fibroblasts. Am J Physiol, v. 277, n. 4 Pt 1, p. C755-65, Oct 1999. ISSN 0002-9513.

Schlichter, L. C., Grygorczyk, R., Pahapill, P. A. \& Grygorczyk, C.. A large, multipleconductance chloride channel in normal human T lymphocytes. Pflugers Arch, v. 416, n. 4, p. 413-21, Jun 1990. ISSN 0031-6768.

Schwarze, W. \& Kolb, H. A. Voltage-dependent kinetics of an anionic channel of large unit conductance in macrophages and myotube membranes. Pflugers Arch, v. 402, n. 3, p. 281-91, Nov 1984. ISSN 0031-6768.

Scocchi, M., Bontempo, D., Boscolo, S., Tomasinsig, L., Giulotto, E. \& Zanetti, M. Novel cathelicidins in horse leukocytes(1). FEBS Lett, v. 457, n. 3, p. 459-64, Sep 1999. ISSN 0014-5793.

Skerlavaj, B., Scocchi, M., Gennaro, R., Risso, A. \& Zanetti, M. Structural and functional analysis of horse cathelicidin peptides. Antimicrob Agents Chemother, v. 45, n. 3, p. 715-22, Mar 2001. ISSN 0066-4804.

Surprenant, A., Rassendren, F., Kawashima, E., North, R. A. \& Buell, G.. The cytolytic P2Z receptor for extracellular ATP identified as a P2X receptor (P2X7). Science, v. 272, n. 5262, p. 735-8, May 1996. ISSN 0036-8075.

Szallasi, A. \& Blumberg, P. M. Vanilloid (Capsaicin) receptors and mechanisms. Pharmacol Rev, v. 51, n. 2, p. 159-212, Jun 1999. ISSN 0031-6997.

Takenouchi, T., Sato, M. \& Kitani, H. Lysophosphatidylcholine potentiates Ca2+ influx, pore formation and p44/42 MAP kinase phosphorylation mediated by P2X7 receptor activation in mouse microglial cells. J Neurochem, v. 102, n. 5, p. 1518-32, Sep 2007. ISSN 0022-3042.

Taylor, S. R., Gonzalez-Begne, M., Dewhurst, S., Chimini, G., Higgins, C. F., Melvin, J. E. \& Elliott, J. I.. Sequential shrinkage and swelling underlie P2X7-stimulated lymphocyte phosphatidylserine exposure and death. J Immunol, v. 180, n. 1, p. 3008, Jan 2008. ISSN 0022-1767.

Thompson, R. J. \& Macvicar, B. A. Connexin and pannexin hemichannels of neurons and astrocytes. Channels (Austin), v. 2, n. 2, p. 81-6, 2008 Mar-Apr 2008. ISSN 1933-6969.

Thompson, R. J., Jackson, M. F., Olah, M. E., Rungta, R. L., Hines, D. J., Beazely, M. A., MacDonald, J. F. \& MacVicar, B. A.. Activation of pannexin-1 hemichannels augments aberrant bursting in the hippocampus. Science, v. 322, n. 5907, p. 1555-9, Dec 2008. ISSN 1095-9203.

Thompson, R. J., Zhou, N. \& Macvicar, B. A. Ischemia opens neuronal gap junction hemichannels. Science, v. 312, n. 5775, p. 924-7, May 2006. ISSN 1095-9203.

Ugur, M., Drummond, R. M., Zou, H., Sheng, P., Singer, J. J. \& Walsh, J. V.. An ATP-gated cation channel with some P2Z-like characteristics in gastric smooth muscle cells of toad. J Physiol, v. 498 ( Pt 2), p. 427-42, Jan 1997. ISSN 0022-3751. 
Virginio, C., Church, D., North, R. A. \& Surprenant, A.. Effects of divalent cations, protons and calmidazolium at the rat P2X7 receptor. Neuropharmacology, v. 36, n. 9, p. 128594, Sep 1997. ISSN 0028-3908.

Virginio, C., MacKenzie, A., Rassendren, F. A., North, R. A. \& Surprenant, A.. Pore dilation of neuronal P2X receptor channels. Nat Neurosci, v. 2, n. 4, p. 315-21, Apr 1999. ISSN 1097-6256.

Voets, T., Droogmans, G., Wissenbach, U., Janssens, A., Flockerzi, V. \& Nilius, B.. The principle of temperature-dependent gating in cold- and heat-sensitive TRP channels. Nature, v. 430, n. 7001, p. 748-54, Aug 2004. ISSN 1476-4687.

Yan, Z., Khadra, A., Li, S., Tomic, M., Sherman, A. \& Stojilkovic, S. S.. Experimental characterization and mathematical modeling of $\mathrm{P} 2 \mathrm{X} 7$ receptor channel gating. $J$ Neurosci, v. 30, n. 42, p. 14213-24, Oct 2010. ISSN 1529-2401.

Yip, L., Woehrle, T., Corriden, R., Hirsh, M., Chen, Y., Inoue, Y., Ferrari, V., Insel, P. A. \& Junger, W. G.. Autocrine regulation of T-cell activation by ATP release and P2X7 receptors. FASEB J, v. 23, n. 6, p. 1685-93, Jun 2009. ISSN 1530-6860.

Young, R. C.; Mclaren, M. \& Ramsdell, J. S. Maitotoxin increases voltage independent chloride and sodium currents in GH4C1 rat pituitary cells. Nat Toxins, v. 3, n. 6, p. 419-27, 1995. ISSN 1056-9014.

$\mathrm{Yu}, \mathrm{W}$. H. \& Forte, M. Is there VDAC in cell compartments other than the mitochondria? J Bioenerg Biomembr, v. 28, n. 2, p. 93-100, Apr 1996. ISSN 0145-479X.

Yuan, B. S., Zhu, R. M., Braddock, M., Zhang, X. H., Shi, W. \& Zheng, M. H.. Interleukin-18: a pro-inflammatory cytokine that plays an important role in acute pancreatitis. Expert Opin Ther 


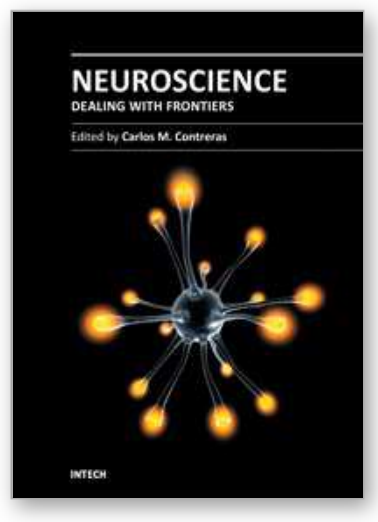

\author{
Neuroscience - Dealing With Frontiers \\ Edited by Dr. Carlos M. Contreras
}

ISBN 978-953-51-0207-6

Hard cover, 440 pages

Publisher InTech

Published online 16, March, 2012

Published in print edition March, 2012

The Neuronal Doctrine recently reached its 100th year and together with the development of psychopharmacology by the middle of 20th century promoted spectacular developments in the knowledge of the biological bases of behavior. The overwhelming amount of data accumulated, forced the division of neuroscience into several subdisciplines, but this division needs to dissolve in the 21 st century and focus on specific processes that involve diverse methodological and theoretical approaches. The chapters contained in this book illustrate that neuroscience converges in the search for sound answers to several questions, including the pathways followed by cells, how individuals communicate with each other, inflammation, learning and memory, the development of drug dependence, and approaches to explaining the processes that underlie two highly incapacitating chronic degenerative illnesses.

\title{
How to reference
}

In order to correctly reference this scholarly work, feel free to copy and paste the following:

R.X. Faria, L.G.B. Ferreira and L.A. Alves (2012). The Mystery of P2X7 lonotropic Receptor: From a Small Conductance Channel to a Large Conductance Channel, Neuroscience - Dealing With Frontiers, Dr. Carlos M. Contreras (Ed.), ISBN: 978-953-51-0207-6, InTech, Available from:

http://www.intechopen.com/books/neuroscience-dealing-with-frontiers/the-mystery-of-p2x7-receptor-from-asmall-channel-to-a-big-pore

\section{INTECH}

open science | open minds

\section{InTech Europe}

University Campus STeP Ri

Slavka Krautzeka 83/A

51000 Rijeka, Croatia

Phone: +385 (51) 770447

Fax: +385 (51) 686166

www.intechopen.com

\section{InTech China}

Unit 405, Office Block, Hotel Equatorial Shanghai No.65, Yan An Road (West), Shanghai, 200040, China 中国上海市延安西路65号上海国际贵都大饭店办公楼405单元 Phone: +86-21-62489820

Fax: $+86-21-62489821$ 
(C) 2012 The Author(s). Licensee IntechOpen. This is an open access article distributed under the terms of the Creative Commons Attribution 3.0 License, which permits unrestricted use, distribution, and reproduction in any medium, provided the original work is properly cited. 